\title{
Geostatistical analysis of soil moisture variability on Da Nangou catchment of the loess plateau, China
}

\author{
Jun Wang $\cdot$ Bojie Fu $\cdot$ Yang Qiu $\cdot$ Liding Chen $\cdot$ Zhi Wang
}

\begin{abstract}
To achieve a better understanding of environmental issues related to soil erosion, flooding, and solute transport, it is necessary to understand the variability of soil moisture under different climatic and geological conditions and at different spatio-temporal scales. Moisture patterns based on five depths $(0-5,15-20,25-30,45-50$, and 70-75 cm) were determined in the Da Nangou catchment of the loess plateau of China from May to September 1999. Spatial structure of profile-averaged and layer-averaged soil moisture was analysed using semivariograms. The results indicated that soil moisture exhibits changing spatial dependence with time and depth. For profile-averaged soil moisture, high sills $\left[4.6-14 \%(\mathrm{v} / \mathrm{v})^{2}\right]$ and high ranges (135-160 m) were observed during dry conditions. The sills $\left[2.6-6.3(\% \mathrm{v} / \mathrm{v})^{2}\right]$ and ranges $(140 \mathrm{~m})$ were small during wet conditions. However, soil moisture was described by linear semivariograms without a sill following a significant rain event. For layeraveraged soil moisture, the sills increased with depth, but not for the ranges. The nuggets tended to increase with higher sills. This analysis provides insights into the variability of soil moisture on a large scale and interpolation strategies for extrapolating point measurements across the catchment.
\end{abstract}

Received: 11 February 2000 / Accepted: 30 March 2001 Published online: 31 May 2001

(C) Springer-Verlag 2001

J. Wang · B. Fu ( $)$ ) Y. Qiu $\cdot$ L. Chen

Department of Systems Ecology,

Research Centre for Eco-Environmental Sciences,

Chinese Academy of Sciences, P.0. Box 2871,

Beijing 100085, China

E-mail: bfu@mail.rcees.ac.cn

Fax: +86-10-62923563

J. Wang

Land Consolidation and Rehabilitation Centre,

Ministry of Land and Resources,

No. 50 Da Jue Alley Xicheng District, Beijing, 100035, China

Z. Wang

Department of Environmental Sciences,

University of California, Riverside, CA 92521, USA
Keywords Soil moisture $\cdot$ Semivariogram $\cdot$ Spatial structure $\cdot$ Loess plateau of China

\section{Introduction}

Soil moisture is critical for addressing environmental issues related to soil erosion, flooding, and solute transport (Kitanidis and Bras 1980; Moore and others 1988; Ritsema and others 1996). However, soil moisture is highly variable in space and time, and its variability results from many processes operating at a wide range of scales influenced by soil type and texture (Zhu 1991), land use (Fu and others 2000), vegetation (Hawley and others 1983), and topography (Famiglietti and others 1998). To achieve a better understanding of these issues, it is necessary to understand the spatio-temporal variability of soil moisture under different climatic and geological conditions and at different hierarchical space scales and time scales (Mohanty and others 2000).

Current emphasis on modelling of runoff and non-point pollution requires extensive field data on soil moisture for model validation because of its impact on water flux patterns. To be of use, the soil moisture data need to be grouped, manipulated, or scaled to bring out spatial dependence and independence, as well as similarities and differences common to areas, or layers of soil. One way of detecting this attribute is by its geostatistical correlation structure in space. Quantitative estimates of this structure are required for a number of purposes including the interpolation strategies from point data and estimation of the average catchment soil moisture.

The geostatistical method using semivariograms was originally developed by mining engineers to asses spatial variability in soil samples for gold ore (Matheron 1963; Webster and Oliver 1990) and then extensively used in the environmental field (Polhmann 1993) to resolve sitespecific problems. The semivariogram has three main features: the sill, the correlation length (range), and the nugget. A semivariogram typically increases from a $Y$ intercept (the nugget), which is usually other than zero, and levels off at a maximum (the sill), which occurs at and beyond a particular lag distance (the range). The range identifies the distance beyond which pairs of points no longer exhibit spatial dependence. The nugget indicates 
the variance at zero distance, which is caused by measurement error or microvariability less than the shortest sampling distance.

Many researchers have studied the spatial variability of surface soil moisture, and Famiglietti and others (1998) and Grayson and Western (1998) have provided comprehensive summaries of their results. However, for most hydrological applications changes in soil moisture over a deeper layer are important (Western and others 1998). For example, accumulation of water in the subsoil can lead to subsurface runoff, even if saturation is incomplete (Burt and Butcher 1985). There is little information in the literature on the spatial structure of moisture over depth. Spatial variability of soil moisture has been assessed using geostatistical methods based on remotely sensed and field measurement data. However, this approach has provided contradictory conclusions in earlier publications. For example, Hills and Reynolds (1969), Loague (1992),

Schmugge and Jackson (1996), and Mohanty and others (2000) have reported little spatial correlation of soil moisture. In contrast, other researchers have found spatial correlation. Some authors have observed small ranges of field soil moisture contents. In the Puebla de Valles-Retiendas of central Spain, Fitzjohn and others (1998) obtained a range of about $18 \mathrm{~m}$ and a sill of $13-24(\% \mathrm{v} / \mathrm{v})^{2}$ in dry conditions, and a range of $51 \mathrm{~m}$ and a sill of 65.7 $(\% \mathrm{v} / \mathrm{v})^{2}$ under wet conditions. Other reported ranges have been as small as $6 \mathrm{~m}$ (Hawley and others 1983) and as large as 3,500 m (Hollenbeck and others 1996). No consensus on spatial dependence, and differences in ranges of $6-3,500 \mathrm{~m}$ suggest that soil moisture is a time-dependent property and thus there is the possibility of changing spatial dependence (Davidson and Watson 1995). Therefore, in order to assess the spatio-temporal structure of soil moisture comprehensively, further investigation is required in various locations, at various depths, and over a large range of scales. We studied the loess plateau of China. Because of peculiar soil formation processes and climatic conditions, loess deposits are widespread in the west of China, constituting the so-called loess plateau. The average erosion rate in this area, the highest rate of erosion in the world, is $150 \mathrm{Mg} \mathrm{ha}^{-1}$ year $^{-1}$ (Chen and Luck 1989). Our objectives were: (1) to analyse seasonal changes in spatial structure of soil moisture, in particular those following a significant rain event; (2) to compare the spatial structures of profile-averaged and layer-averaged soil moisture contents; and (3) to discuss the implications for interpolation strategies and estimate variability of moisture over a large scale.

\section{Materials and methods}

\section{Study area}

The Da Nangou catchment $\left(36^{\circ} 53 \mathrm{~N}, 109^{\circ} 17^{\mathrm{E}}\right)$ is situated near the centre of the loess plateau in northern Shaanxi province, China. The catchment has an area of $3.5 \mathrm{~km}^{2}$ and an altitude of 1,000-1,350 m. Prolonged human activities have destroyed all the natural vegetation, and the land use was a mosaic of slope cropland, fallow land, grassland, shrub land, and woodland.

The region has a semiarid continental climate with an average annual temperature of $8.8^{\circ} \mathrm{C}$. Monthly mean temperatures range from $22.5^{\circ} \mathrm{C}$ in July to $-7^{\circ} \mathrm{C}$ in January. The average annual precipitation is $562 \mathrm{~mm}$ with great interannual variability, and $60 \%$ of the rainfall falls between July and September.

Soil of the study area developed on wind-deposited loess parent material. The soil is classified as Calcic Cambisol in FAO/UNESCO/ISRIC (1988) soil classification. The predominant soil in the study area is loess and has a texture of silt ranging from 64 to $73 \%$ and clay varying from 17 to $20 \%$. It is weekly resistant to erosion.

\section{Sampling methods}

Four adjacent hillslope transects spread over two subcatchments were selected to measure soil moisture content (Fig. 1). The four transects gave a total of 67 sampling points at $20 \mathrm{~m}$ intervals. Volumetric soil moisture was measured using a ThetaProbe Soil Moisture Sensor Type ML1 (Delta-T Devices, Eijkelkamp Agrisearch Equipment, The Netherlands). Its accuracy was checked by measurements on 12 samples with gravimetrically determined water contents ranging from saturated to permanent wilting point. The mean square root error was $0.0203(\mathrm{v} / \mathrm{v})$.

Soil moisture was measured at intervals of approximately 2 weeks from May to September 1999, and also every second or third day after all significant rain events. After augering to the measuring depth, four parallel steel rods (length $6 \mathrm{~cm}$, diameter $0.3 \mathrm{~cm}$, and spacing $2.5-3 \mathrm{~cm}$ ) were inserted vertically into the soil, and remained in position until the displayed value of the ThetaProbe

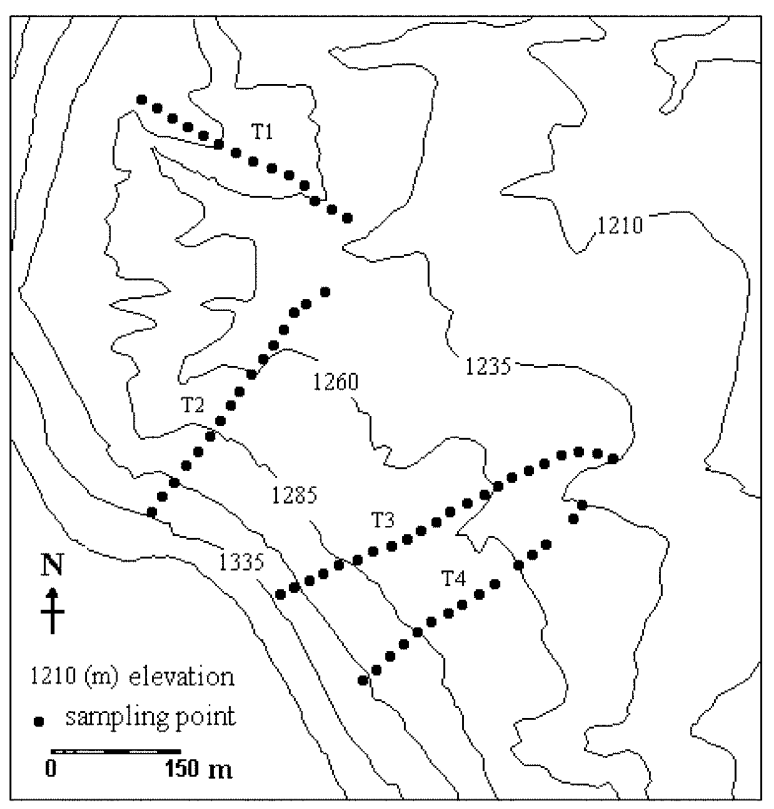

Fig. 1

Spatial distribution of sampling points in the Da Nangou catchment (T1 transect 1, T2 transect 2, T3 transect 3, T4 transect 4) 
stabilized. Because of the destructive nature of this method, measurements were taken at five random locations within a 2-m-diameter circle around each point. Moisture was measured at five depths: 0-5, 15-20, 25-30, $45-50$, and $70-75 \mathrm{~cm}$. Mean soil moisture contents were calculated for each depth (layer-averaged moisture) and for the whole profile (profile-averaged moisture) at each site. Average rainfall was recorded by five automatic datalogged raingauges located in the catchment.

\section{Statistical methods}

Statistical analysis of these data was performed in three steps: (1) frequency distributions were examined and normality tests assessed; (2) the distributions were described using classical statistics to obtain means, variances $\left(\sigma^{2}\right)$, coefficients of variation (CV), medians, ranges; and (3) semivariograms were constructed and fitted to curve types. The descriptive statistics, such as the mean, $\sigma^{2}$, and CV, were calculated using SPSS software (SPSS Inc. 1993), and normality was assessed using the one-sample Kolomogorov-Smirnov (KS) test for goodness-of-fit, also in SPSS.

We used ILWIS (1998) to analyse the spatial structure of the data with the semivariograms. Semivariance was calculated for lag distances up to $240 \mathrm{~m}$ (12 intervals), which was slightly less than half the maximum separation distance between sampling points. Each distance class contained at least 57 pairs of points for the calculation of semivariance and most contained $>80$ pairs of data points. Because 53 of 67 sampling points were located in transects 2,3 , and 4 , which were all north facing (Fig. 1), isotropic models were used.

The semivariance $(\gamma(h))$ was estimated by:

$\gamma(h)=\frac{1}{2 N(h)} \sum_{i=1}^{N(h)}\left[Z\left(x_{i}\right)-Z\left(x_{i}+h\right)\right]^{2}$

where $Z$ is soil moisture, $x$ is the sample location, and $N(h)$ is the number of pairs of locations separated by a lag distance $h$.

The following spherical [Eq. (2)] and exponential [Eq. (3)] models with a nugget were fitted to the experimental semivariograms:
$\left\{\begin{array}{lll}\gamma(h)=C_{0}+C\left(\frac{3}{2} \frac{h}{a}-\frac{1}{2} \frac{h^{3}}{a^{3}}\right) & \text { as } & h \leq a \\ \gamma(h)=C_{0}+C & \text { as } & h \geq a\end{array}\right.$

$\gamma(h)=C_{0}+C\left(1-e^{-\frac{h}{a}}\right)$

where $\gamma(h)$ is the semivariogram, $C_{0}$ is the nugget, $\left(C_{0}+C\right)$ is the sill, and $a$ is the correlation length. The practical range for the exponential model is $3 a$, which is the point at which $\gamma(h)$ reaches $95 \%$ of the sill (Webster 1985). The quality of the semivariogram fit to the data was indicated using $R^{2}$ regression and an $F$-test calculated as:

$F=\frac{R^{2}}{1-R^{2}} \times \frac{N-k}{k-1}$

where $N$ is the number for samples and $k$ is the number of variables in the regression model.

\section{Results}

\section{Descriptive statistical analysis}

Spatial patterns of soil moisture were measured 12 times over the whole observation period. Table 1 shows the descriptive statistics for these profile-averaged moisture patterns. There are clear differences in the statistical characteristics of soil moisture between wet (12 July, 15 July, and 22 July) and dry (2 May and 23 May) conditions. In the wet conditions, the catchment had high soil moisture content, resulting from $105 \mathrm{~mm}$ rainfall during July (Table 1), whereas the CV and $\sigma^{2}$ values were small, indicating that the distribution of moisture was relatively uniform over the catchment. However, in the dry conditions, $\mathrm{CV}$ and $\sigma^{2}$ values were larger than for the wet conditions. During very dry conditions (9 September), because any available soil moisture evaporated quickly and evapotranspiration is moisture limited, the mean, range, and $\sigma^{2}$ values were small.

The mean and median values of soil water content for the 12 patterns were similar, indicating that these measures of
Table 1

Descriptive statistics for profile-averaged soil moisture in the Da Nangou catchment. $\sigma^{2}$ Variance; $C V$ coefficient of variation; $K S$ one-sample Kolomogorov-Smirnov test

\begin{tabular}{|c|c|c|c|c|c|c|c|}
\hline Date & $\begin{array}{l}\text { Rainfall }^{a} \\
(\mathrm{~mm})\end{array}$ & $\begin{array}{l}\text { Mean } \\
(\% \mathrm{v} / \mathrm{v})\end{array}$ & $\begin{array}{l}\sigma^{2} \\
(\% \mathrm{v} / \mathrm{v})^{2}\end{array}$ & $\begin{array}{l}\text { CV } \\
(\%)\end{array}$ & $\begin{array}{l}\text { Median } \\
(\% \mathrm{v} / \mathrm{v})\end{array}$ & $\begin{array}{l}\text { Range } \\
(\% \mathrm{v} / \mathrm{v})\end{array}$ & KS value \\
\hline 2-Мay-99 & 7.1 & 10.20 & 10.43 & 32 & 9.73 & 16.62 & 0.204 \\
\hline 13-Мау-99 & 2.5 & 7.77 & 14.98 & 50 & 6.79 & 18.64 & 0.003 \\
\hline 23-Мау-99 & 23.7 & 9.53 & 10.89 & 35 & 8.87 & 14.70 & 0.02 \\
\hline 10-Jun-99 & 1.7 & 6.11 & 5.95 & 40 & 5.63 & 12.71 & 0.01 \\
\hline 23-Jun-99 & 13.2 & 7.72 & 4.58 & 28 & 7.55 & 12.47 & 0.465 \\
\hline 12-Jul-99 & 67.7 & 16.06 & 6.60 & 16 & 15.92 & 13.32 & 0.699 \\
\hline 15-Jul-99 & 3.2 & 15.44 & 3.80 & 12 & 15.47 & 10.71 & 0.139 \\
\hline 18-Jul-99 & 0.2 & 11.85 & 2.62 & 14 & 11.97 & 7.37 & 0.228 \\
\hline 22-Jul-99 & 33.7 & 18.43 & 5.06 & 12 & 18.49 & 12.02 & 0.129 \\
\hline 30-Jul-99 & 0.2 & 11.23 & 6.05 & 22 & 11.68 & 11.18 & 0.018 \\
\hline 10-Aug-99 & 13.9 & 11.11 & 4.88 & 20 & 11.45 & 9.46 & 0.038 \\
\hline 9-Sep-99 & 5.4 & 5.85 & 3.03 & 30 & 5.81 & 8.81 & 0.039 \\
\hline
\end{tabular}

${ }^{\mathrm{a}}$ Represents the rainfall of the intervals between consecutive measurement dates 
central tendency were not dominated by outliers in the distributions. The KS test ( $\alpha=0.05$ probability level) also indicated that most of the profile-averaged soil moisture data were either normally distributed or close to it (Table 1).

Descriptive characteristics of layer-averaged soil moisture were also analysed. The mean increased with depth in dry conditions (between 2 May and 23 June), but decreased in wet conditions (12 July, 15 July, and 22 July). Nevertheless, in both dry and wet conditions the $\sigma^{2}$ values increased with depth below $5 \mathrm{~cm}$. The CV values at $70-75 \mathrm{~cm}$ exhibited small fluctuation between 23 and $43(\% \mathrm{v} / \mathrm{v})$ over the whole observation period. However, after a significant rain event, the $\mathrm{CV}$ values for layers below $5 \mathrm{~cm}$ increased with depth between 12 July and 10 August.

\section{Seasonal evolution of the spatial structure of profile-averaged soil moisture}

The parameters of the fitted semivariograms for profileaveraged soil moisture data summarized in Table 2 were generated from the spherical [Eq. (2)] and exponential [Eq. (3)] models, which are the best fitting descriptors for this data set. All the semivariogram models are acceptable for fitting to the raw data according to the F-test [Eq. (4)] and have $R^{2}$ values ranging from 0.52 to 0.87 (Table 2).

The seasonal evolution of the spatial structure of profileaveraged soil moisture is shown in Table 2 and Fig. 2. The sill values ranged from 2.6 to $14(\% \mathrm{v} / \mathrm{v})^{2}$ and showed a clear seasonal trend. During May and June the mean soil moisture content was small because of low evapotranspiration and little rainfall $(48.2 \mathrm{~mm}$ between 2 May and 23 June), but the spatial pattern was very variable, and so the sill was high. This high variability mainly results from the effects of relative elevation, hillslope position, slope degree, and land use on moisture (Qiu and others, unpublished). In July, with the approaching rainy season, the mean was greater despite high evapotranspiration, and the spatial distribution of moisture was more uniform, so the sill was low. The low sill values were mainly attributed to the increasing rainfall (105 $\mathrm{mm}$ in July), which influenced the redistribution of moisture more strongly. As the soil dried, the moisture content decreased, but its spatial variability increased because of irregular evapotranspiration and redistribution of moisture, and then decreased again. Consequently, the sill was $6.3(\% \mathrm{v} / \mathrm{v})^{2}$ on $30 \mathrm{July}$ and $4.7(\% \mathrm{v} / \mathrm{v})^{2}$ on 10 August. On 9 September the variance decreased slightly during very dry conditions. From 10 August to 9 September little rain $(5.4 \mathrm{~mm})$ fell, so evapotranspiration was moisture limited, and the mean soil moisture content was only $5.85(\% \mathrm{v} / \mathrm{v})$, which is close to the wilting point. Since the wilting point is uniform across the catchment, this resulted in a decrease of the sill. After a major storm event that produced runoff over the whole catchment, soil moisture on 12 July was described by linear semivariograms without a sill (Table 2). Semivariances increasing continuously without development of a sill indicated trend effects (Webster and Burgess 1980; Yost and others 1982). The variances decreased slowly with time (on 15 July and 18 July) but later increased because of extensive saturation. After a second rain event soil moisture variances on 22 July gave a linear semivariogram without a sill similar to the pattern after the first event.

The range values also exhibited a seasonal pattern, showing smaller values during wet periods and larger values during dry periods (Fig. 2). During May and June the ranges were large because moisture redistribution was limited by the small amount of rain. In July, moisture redistribution was active and land use could have led to different wet strips. Therefore, these were small ranges. During very dry conditions moisture was uniform and evaporation had the main impact on the moisture pattern, resulting in an increase the range.

Unlike the sill and range, the nugget loosely followed the seasonal pattern of mean soil moisture content (Fig. 2). Nugget comprises all unaccounted-for experimental error and spatial variability at distances smaller than the smallest sampling space, whereas the semivariogram models the structural spatial dependence. Consequently, the ratio of nugget variance to sill variance expressed as a percentage can be regarded as an indication of the spatial
Table 2

Summary of parameters of semivariograms for profileaveraged soil moisture in the Da Nangou catchment.

$\left[F(1,10)_{0.05}=4.85\right.$, $\left.F(1,10)_{0.01}=9.6\right]$. Spatial class: $S$ strong spatial dependence (nugget/sill \% <25); $M$ moderate spatial dependence (nugget/sill $\%$ 25-75); $W$ weak spatial dependence (nugget/sill $\%>75$ )

\begin{tabular}{|c|c|c|c|c|c|c|}
\hline Date & $\begin{array}{l}\text { Nugget } \\
(\% \mathrm{v} / \mathrm{v})^{2}\end{array}$ & $\begin{array}{l}\text { Sill } \\
(\% \mathrm{v} / \mathrm{v})^{2}\end{array}$ & $\begin{array}{l}\text { Range } \\
(\mathrm{m})\end{array}$ & $R^{2}$ & $F$-value & $\begin{array}{l}\text { Spatial } \\
\text { class }\end{array}$ \\
\hline $2-$ May- $99^{\mathrm{a}}$ & 1.5 & 9.4 & 135 & 0.68 & $23.38^{\star *}$ & $S$ \\
\hline 13-May-99 & 1 & 14 & 140 & 0.74 & $31.31^{\star *}$ & $S$ \\
\hline 23-Мау-99 & 1.1 & 11.5 & 160 & 0.8 & $44.00^{\star *}$ & S \\
\hline 10-Jun-99 ${ }^{\mathrm{a}}$ & 0.5 & 5.7 & 150 & 0.76 & $34.83^{\star *}$ & S \\
\hline 23-Jun-99 & 0.2 & 4.6 & 159 & 0.66 & $21.35^{\star *}$ & $S$ \\
\hline 12-Jul-99 & $\begin{aligned} Y= & 0.0192 x \\
& +1.4224\end{aligned}$ & & - & 0.84 & $57.75^{\star *}$ & - \\
\hline 15-Jul-99 & 1 & 3.6 & 140 & 0.67 & $22.33^{\star *}$ & M \\
\hline 18-Jul-99 & 0.8 & 2.6 & 140 & 0.52 & $11.92^{* *}$ & M \\
\hline 22-Jul-99 & $\begin{aligned} Y= & 0.0171 x \\
& +1.4623\end{aligned}$ & & - & 0.87 & $73.62^{* *}$ & - \\
\hline 30-Jul-99 & 1 & 6.3 & 140 & 0.64 & $19.56^{\star *}$ & $S$ \\
\hline 10-Aug-99 & 0.9 & 4.7 & 140 & 0.63 & $18.73^{* *}$ & $S$ \\
\hline 9-Sep-99 & 0.2 & 2.7 & 160 & 0.77 & $36.83^{\star \star}$ & $S$ \\
\hline
\end{tabular}

${ }^{\mathrm{a}}$ Semivariograms are exponential; the others are spherical

${ }^{*}$ Significance at $\alpha<0.05$ level; ${ }^{* *}$ significance at $\alpha<0.01$ level 

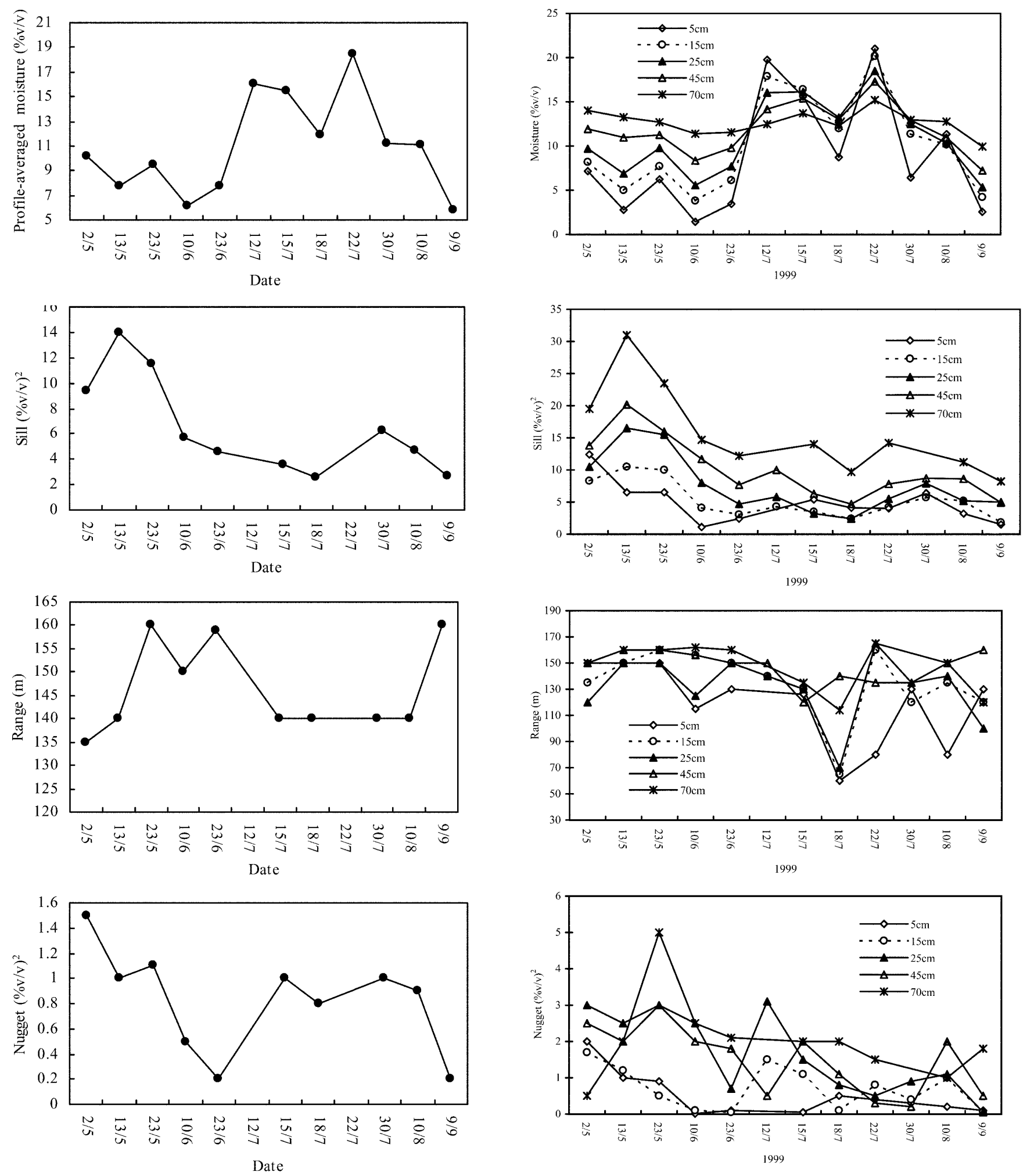

Fig. 2

Seasonal evolution of geostatistical structure for the profile-averaged soil moisture in the Da Nangou catchment

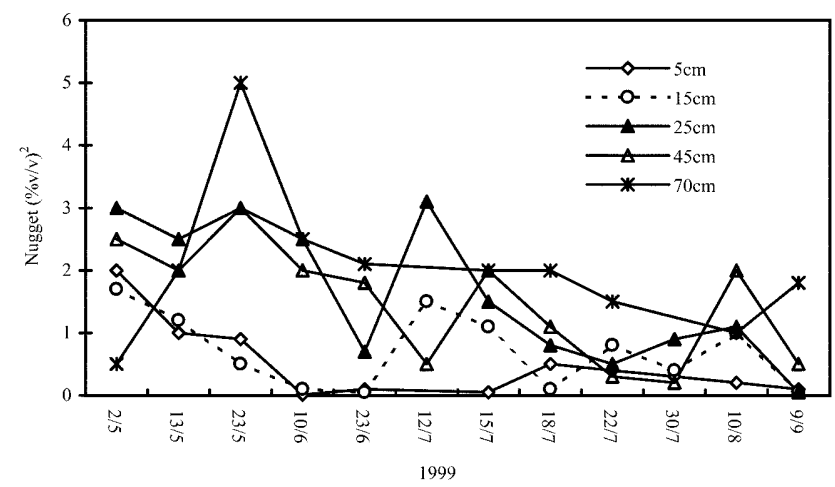

Fig. 3

Seasonal evolution of geostatistical structure for the layer-averaged soil moisture in the Da Nangou catchment

dependence of the variable concerned. If the ratio is $<25 \%$, the variable has strong spatial dependence. It has moderate spatial dependence for ratios between 25 and $75 \%$ and weak spatial dependence for ratios $>75 \%$ (Chien and

others 1997). The ratio of nugget variance to sill variance for all the semivariograms of profile-averaged moisture ranged from 4 to $31 \%$ (Table 2), indicating strong to moderate spatial dependence. 


\section{Seasonal evolution of the spatial structure of layer-averaged soil moisture}

Figure 3 shows seasonal evolution of the sill, range, and nugget values for the five depth layers. As expected, the sills exhibited a clear seasonal pattern and fluctuations for the five depths were synchronous. The sills increased with depth during the whole observation period except for 2 May, and 15, 18, and 22 July, which had greater values at $0-5 \mathrm{~cm}$ than at $15-20 \mathrm{~cm}$ depth. The high sills at $0-5 \mathrm{~cm}$ may be due to meteorological conditions such as radiation and temperature (Anderson and Burt 1978; Barling and others 1994; Famiglietti and others 1998). Moreover, the sills for all layers were high during May and June. During July, following the significant storm event that caused widespread runoff over the whole catchment, there was vertical redistribution of moisture, and soil moisture contents were high, but the sills were small (Fig. 3), implying that the rain event resulted in a decrease in spatial variability of moisture. As the soil dried, the spatial variability of the five layers increased because of the evapotranspiration and redistribution of moisture. However, under very dry conditions (9 September), the larger moisture deficit and greater evapotranspiration rate resulted in mean soil moisture contents between $2.55(\% \mathrm{v} / \mathrm{v})$ at $0-5 \mathrm{~cm}$ and $9.93(\% \mathrm{v} / \mathrm{v})$ at $70-75 \mathrm{~cm}$. These extremes are below or close to the wilting point, so soil moisture had became more uniform across the catchment and this probably explain the low sills.

In contrast to the sill, the range did not exhibit seasonal changes in any of the five layers (Fig. 3). Its changes at 45-50 and 70-75 cm depths were less than those for $0-5,15-20$, and $25-30 \mathrm{~cm}$ over the whole observation period. Before the earlier storm event which resulted in runoff (12 July), the ranges at $0-5,15-20$, and $25-30 \mathrm{~cm}$ showed similar changes, whereas those at 45-50 and $70-75 \mathrm{~cm}$ showed small fluctuations between 150 and $160 \mathrm{~m}$. However, the range showed more complex changes following this rainfall event, clearly indicating that the event caused redistribution processes of moisture.
Influence of methods on spatial structure

In order to explore the influence of sampling depth on spatial structure of soil moisture further, we calculated the mean parameters of semivariograms for two layers $(0-15 \mathrm{~cm})$, three layers $(0-25 \mathrm{~cm})$, four layers $(0-45 \mathrm{~cm})$, and all five layers $(0-70 \mathrm{~cm})$. Table 3 shows the mean sill, range, and nugget of the fitted models for these groups of layers. The three parameters vary with depth in different ways. The mean sill for two, three, four, and five layers showed a clear increase with depth (Table 3), and the mean sill for five depths was greater than that for the profileaveraged soil moisture content. These comparisons imply that the parameters of semivariograms can differ with sampling depth even if samples are collected at the same location. Therefore, sampling depth should be considered in any comparisons of the spatial structure of soil moisture.

\section{Discussion and conclusions}

Twelve soil moisture patterns based on five depths (0-5, $15-20,25-30,45-50$, and 70-75 cm) from May to September 1999 were determined in the $3.5 \mathrm{~km}^{2}$ Da Nangou catchment in the loess plateau of China. Profile-averaged and layer-averaged soil moisture were analysed using geostatistics. Spherical and exponential semivariogram models with a nugget fitted the sample semivariograms closely.

The benefit of geostatistical analysis of the time series approach is that it provides a consistent picture of spatial correlation for soil moisture, which enhances our ability to understand the attribute of spatial variability of soil moisture. An important result derived from our study is that soil moisture exhibits changing spatial dependence with time. This means that different interpolation strategies would be used to provide moisture estimates by extrapolating point measurements across the catchment. If soil moisture behaves dependently, for example in dry conditions in our study, kriging would be the preferred method of interpolation for moisture estimate, while in the

Table 3

Comparison of mean parameters of semivariograms between layers and profile-averaged soil moisture

\begin{tabular}{|c|c|c|c|c|c|c|c|c|c|c|c|c|c|c|c|}
\hline \multirow[t]{2}{*}{ Date } & \multicolumn{5}{|c|}{ Nugget $(\% \mathrm{v} / \mathrm{v})^{2}$} & \multicolumn{5}{|c|}{ Sill $(\% \mathrm{v} / \mathrm{v})^{2}$} & \multicolumn{5}{|c|}{ Range (m) } \\
\hline & $\begin{array}{l}\text { Two } \\
\text { layers }\end{array}$ & $\begin{array}{l}\text { Three } \\
\text { layers }\end{array}$ & $\begin{array}{l}\text { Four } \\
\text { layers }\end{array}$ & $\begin{array}{l}\text { Five } \\
\text { layers }\end{array}$ & $\begin{array}{l}\text { Profile- } \\
\text { aver- } \\
\text { aged }\end{array}$ & $\begin{array}{l}\text { Two } \\
\text { layers }\end{array}$ & $\begin{array}{l}\text { Three } \\
\text { layers }\end{array}$ & $\begin{array}{l}\text { Four } \\
\text { layers }\end{array}$ & $\begin{array}{l}\text { Five } \\
\text { layers }\end{array}$ & $\begin{array}{l}\text { Profile- } \\
\text { aver- } \\
\text { aged }\end{array}$ & $\begin{array}{l}\text { Two } \\
\text { layers }\end{array}$ & $\begin{array}{l}\text { Three } \\
\text { layers }\end{array}$ & $\begin{array}{l}\text { Four } \\
\text { layers }\end{array}$ & $\begin{array}{l}\text { Five } \\
\text { layers }\end{array}$ & $\begin{array}{l}\text { Profile- } \\
\text { aver- } \\
\text { aged }\end{array}$ \\
\hline 2-May-99 & 1.85 & 2.23 & 2.30 & 1.94 & 1.50 & 10.35 & 10.40 & 11.25 & 12.90 & 9.40 & 142.5 & 135.0 & 138.8 & 141 & 135 \\
\hline 13-May-99 & 1.10 & 1.57 & 1.68 & 1.74 & 1.00 & 8.50 & 11.17 & 13.43 & 16.94 & 14.00 & 150.0 & 150.0 & 152.5 & 154 & 140 \\
\hline 23-Мау-99 & 0.70 & 1.47 & 1.85 & 2.48 & 1.10 & 8.25 & 10.67 & 12.00 & 14.30 & 11.50 & 155.0 & 153.3 & 155.0 & 156 & 160 \\
\hline 10-Jun-99 & 0.06 & 0.87 & 1.15 & 1.42 & 0.50 & 2.60 & 4.40 & 6.23 & 7.92 & 5.70 & 135.5 & 132.0 & 138.0 & 142.8 & 150 \\
\hline 23-Jun-99 & 0.08 & 0.28 & 0.66 & 0.95 & 0.20 & 2.73 & 3.38 & 4.46 & 6.01 & 4.60 & 140.0 & 143.3 & 145.0 & 148 & 159 \\
\hline 12-Jul-99 & 1.50 & 2.30 & 1.70 & 1.70 & - & 4.30 & 5.05 & 6.70 & 6.70 & - & 140.0 & 140.0 & 143.3 & 143.3 & - \\
\hline 15-Jul-99 & 0.58 & 0.88 & 1.16 & 1.33 & 1.00 & 4.45 & 4.03 & 4.60 & 6.48 & 3.60 & 128.0 & 128.7 & 126.5 & 128.2 & 140 \\
\hline 18-Jul-99 & 0.30 & 0.47 & 0.63 & 0.90 & 0.80 & 3.25 & 2.97 & 3.40 & 4.66 & 2.60 & 62.5 & 65.0 & 83.8 & 89.8 & 140 \\
\hline 22-Jul-99 & 0.60 & 0.57 & 0.50 & 0.70 & - & 4.10 & 4.57 & 5.38 & 7.14 & - & 120.0 & 135.0 & 135.0 & 141 & - \\
\hline 30-Jul-99 & 0.35 & 0.53 & 0.45 & 0.45 & 1.00 & 6.05 & 6.67 & 7.18 & 7.18 & 6.30 & 125.0 & 128.3 & 130.0 & 130 & 140 \\
\hline 10-Aug-99 & 0.60 & 0.77 & 1.08 & 1.06 & 0.90 & 4.20 & 4.53 & 5.55 & 6.68 & 4.70 & 107.5 & 118.3 & 126.3 & 131 & 140 \\
\hline 9-Sep-99 & 0.08 & 0.07 & 0.18 & 0.50 & 0.20 & 1.66 & 2.77 & 3.31 & 4.28 & 2.70 & 125.0 & 116.7 & 127.5 & 126 & 160 \\
\hline
\end{tabular}


absence of spatial dependence, for example following a significant rain event in our study, traditional statistical techniques can be used.

Measurements taken in layers through the profile allowed us to explore the geostatistical structure of moisture with depth. Our results indicated that the sills increased with depth below $5 \mathrm{~cm}$, but that the ranges did not show any other patterns with depth during observation period. Because the range value can be used as a guide to indicate the size of areas of different moisture contents and spatial frequency of soil moisture changes (Davidson and Watson 1995), soil moisture change patterns of the subsurface are different to those of the surface in our study. This implies that the connectivity of subsurface pathways may be quite different when compared to the connectivity of hydrological pathways at the surface. Surface soil moisture content interpolated from measurement point data is useful to identify potential continuity of flow pathways. This continuity may be very helpful for event-based erosion models, but for solute transport prediction, would lead to errors. In this instance a subsurface conduit derived from geostatistical analysis may be more reasonable. The ranges at Da Nangou vary between 60 and $160 \mathrm{~m}$. It is important to note that the values do not agree with those reported in the literature. Ranges indicated by Hawley and others (1983), Fitzjohn and others (1998), and Western and others (1998) are shorter than those at Da Nangou, while those indicated by Hollenbeck and others (1996) and Bárdossy and Lehmann (1998) are longer. Close inspection of these data reveals that there is a tendency for data collected at larger spacings to have larger ranges. Therefore, some of the differing findings may be explained by differences in the spacing of samples. Some may be explained by differences in climate, soils, vegetation, and topography. In generalizing the results found at Da Nangou, it is important to recognize that soil was uniform across the catchment and the scale was small, based on $3.5 \mathrm{~km}^{2}$. Multiple soils are likely to increase soil moisture variability. Differences in soils are likely to occur at the regional scale. Climate and geology will also become more variable at a regional scale. Because the scale of variability of these control factors tends to be large, it is likely that the range of soil moisture would be larger than for the $\mathrm{Da}$ Nangou catchment.

Acknowledgments The project was supported by the National Natural Science Foundation of China (contract no. 49725101) and INCO-DC of the European Commission (contract no. ERBIC18CT970158). The authors wish to acknowledge the members of the project team for measuring the soil moisture in the field. Special gratitude is expressed to two anonymous reviewers for their valuable suggestions for improving the manuscript.

\section{References}

Anderson MG, Burt TP (1978) Toward a more detailed field monitoring of variable source areas. Water Resour Res 14:1123-1131 Bárdossy A, Lehmann W (1998) Spatial distribution of soil moisture in a small catchment. Part 1: Geostatistical analysis. J Hydrol 206:1-15
Barling RD, Moore ID, Grayson RB (1994) A quasi-dynamic wetness index for characterizing the spatial distribution of zones of surface saturation and soil water content. Water Resour Res 30:1029-1044

Burt TP, Butcher DP (1985) Topographic controls of soil moisture distribution. J Soil Sci 36:469-486

Chen YZ, Luck SH (1989) Sediment sources and recent changes in the sediment load of yellow River, China. In: Rindwanich S (ed) Land conservation for future generations. Ministry of Agriculture, Bangkok, pp 313-323

Chien YL, Lee DY, Guo HY, Houng KH (1997) Geostatistical analysis of soil properties of mid-west Taiwan soils. Soil Sci 162:291-297

Davidson DA, Watson AI (1995) Spatial variability in soil moisture as predicted from airborne thematic mapper (ATM) data. Earth Surf Process Landform 20:219-230

Famiglietti JS, Rudnicki JW, Rodell M (1998) Variability in surface moisture content along a hillslope transect: Rattlesnake Hill Texas. J Hydrol 210:259-281

FAO/UNESCO/ISRIC (1988) Soil map of the world; revised legend. Word Soil Resource Report No. 60. FAO, Rome

Fitzjohn C, Ternan JL, Williams AG (1998) Soil moisture variability in a semi-arid gully catchment: implications for runoff and erosion control. Catena 32:55-70

Fu B, Chen L, Ma K, Zhou H, Wang J (2000) The relationships between land use and soil conditions in the hilly area of the loess plateau in northern Shaanxi, China. Catena 39:69-78

Grayson RB, Western AW (1998) Towards areal estimation of soil water content from point measurements: time and space stability of mean response. J Hydrol 207:68-82

Hawley ME, Jackson TJ, McCuen RH (1983) Surface soil moisture variation on small agricultural watersheds. J Hydrol 62:179-200

Hills RC, Reynolds SG (1969) Illustrations of soil moisture variability in selected areas and plots of different sizes. J Hydrol 8:27-47

Hollenbeck KJ, Schmugge TJ, Hornberger GM, Wang JR (1996) Identifying soil hydraulic heterogeneity by detection of relative change in passive microwave remote sensing observations. Water Resour Res 32:139-148

ILWIS (International Institute for Aerospace Survey and Earth Sciences) (1998) ILWIS 2.2 for Windows. Enschede, The Netherlands

Kitanidis PK, Bras RL (1980) Real time forecasting with a conceptual hydrological model. 2. Applications and results. Water Resour Res 16:1034-1044

Loague K (1992) Soil water content at R-5. Part 1. Spatial and temporal variability. J Hydrol 139:233-251

Matheron G (1963) Principles of geostatistics. Econ Geol 58:12461266

Mohanty BP, Skaggs TH, Famiglietti JS (2000) Analysis and mapping of field-scale soil moisture variability using high-resolution ground-based data during the Southern Great Plains 1997 (SGP97) Hydrology Experiment. Water Resour Res 36(4):1023-1031

Moore ID, Burch GJ, Mackenzie DH (1988) Topographic effects on the distribution of surface soil water and the location of ephemeral gullies. Trans Am Soc Agric Eng 31:1098-1107

Polhmann H (1993) Geostatistical modeling of environmental data. Catena 20:191-198

Ritsema CJ, Stolte J, Oostindie K, van den Elsen E, van Dijk PM (1996) Measuring and modelling of soil water dynamics and runoff generation in an agricultural loessial hillslope. Hydrol Process 10(8):1081-1090

Schmugge TJ, Jackson TJ (1996) Soil moisture variability. In: Stewart JB, Engman ET, Feddes RA, Kerr Y (eds) Scaling-up in hydrology using remote sensing. Wiley, Chichester

SPSS Inc (1993) SPSS for Widows base system user's guide release 6.0. Marija J.Norusis, Chicago 
Webster R (1985) Quantitative spatial analysis of soil in the field. Adv Soil Sci 3:1-70

Webster R, Burgess TM (1980) Optimal interpolation and isarithmic mapping of soil properties. III Changing drift and universal kriging. J Soil Sci 31:505-524

Webster R, Oliver MA (1990) Statistical methods in soil and land resource survey. Oxford University Press, Oxford
Western AW, Blöschl G, Grayson RB (1998) Geostatistical characterisation of soil moisture patterns in the Tarrawarra catchment. J Hydrol 205:20-37

Yost RS, Uehara G, Fox RL (1982) Geostatistical analysis of soil chemical properties of large land areas. I. Semi-variograms. Soil Sci Soc Am J 46:1028-1032

Zhu Z (1991) Soil science (in Chinese). Agriculture Press, Beijing 